\title{
Czarny Styczeń - reakcja zachodniego świata
}

$\mathrm{P}$ rzedmiotem niniejszego artykułu jest reakcja zachodniego świata na masakrę cywilnych mieszkańców Baku dokonaną przez armię radziecką, która miały miejsce 19/20 stycznia 1990 r. i przeszła do historii, jako „Czarny Styczeń”. Większość zdarzeń, także te dotyczące funkcjonowania państw, czy relacji międzynarodowych jest rozpatrywana ze względu na ich faktyczny charakter (obiektywna ocena wydarzeń). Bardzo jednak istotną perspektywą, zwłaszcza w sferze jaką zajmują się nauki o polityce, jest spojrzenie na dane zjawisko w kontekście reakcji na nie innych podmiotów, jej (reakcji) charakteru (biorąc pod uwagę różne czynniki) oraz przyczyn. Wskazana perspektywa ma bardzo istotne znaczenie, zwłaszcza w momencie zachodzenia danego zjawiska. Podkreślić należy jednak jej dużą wagę także w procesie badawczym analizowanych wydarzeń, gdyż jedynie osadzając wspomniane zjawiska w kontekście otaczającej rzeczywistości, możemy w pełni je poznać i określić ich charakter. Jak więc widać tytułowa problematyka jest bardzo istotna dla kwestii badań nad tym, co miało miejsce w Baku, 19/20 stycznia 1990 r. Jest ona tym ważniejsza, że początkowa reakcja Zachodu była odwrotna niż ta, jakiej można się było spodziewać po tak tragicznych wydarzeniach. Powyższe elementy oraz fakt, iż sama problematyka dotycząca wspomnianych wydarzeń jest stosunkowo rzadko poruszana przez polskich naukowców, (choć w mniejszym stopniu także europejskich i światowych) jak też praktyczny brak prac badawczych dotyczących kwestii reakcji świata na to, co miało miejsce podczas „Czarnego Stycznia" powodują, iż badania dotyczące tytułowej kwestii będą stanowiły istotny wkład nie tylko w polską naukę, ale również w badania europejskie i światowe.

W artykule postawione zostały następujące pytania badawcze: dlaczego świat zachodni, a zwłaszcza jego najistotniejsi przedstawiciele, jak m.in. USA, Wielka Brytania czy Włochy nie wspierał (choćby werbalnie) narodu azerbejdżańskiego w krytycznych chwilach „Czarnego Stycznia”, a często odwrotnie, wyrażał aprobatę dla działań reżimu komunistycznego rządzącego w ZSRR?; jakie były przyczyny zmian, (post-factum) w podejściu do tamtych wydarzeń? oraz jaki jest ostateczny bilans odnośnie roli Zachodu w kwestii „Czarnego Stycznia”

W odpowiedzi na wskazane pytania pomocna będzie weryfikacja następującej hipotezy badawczej: reakcja państw i mediów zachodnich, $w$ dużej mierze wspierajacych działania ZSRR na terytorium Azerbejdżańskiej SRR była głównie wynikiem wcześniejszych działań Związu Radzieckiego - blokady informacyjnej, zastosowanej na dtugo przed wydarzeniami zwanymi Czarnym Styczniem i propagandy ZSRR ukazujacej nieprawdziwy obraz Azerbejdżan, jako strony inicjujacej konflikt z Armeńska SRR i stosującej przemoc wobec Ormian. Powściagliwość, a nawet aprobata wyrażona przez duża czesść państw Zachodu, wobec krwawej interwencji wojsk radzieckich $w$ Azerbejdżańskiej SRR nie byłaby 
jednak faktem, gdyby nie postrzeganie przez państwa zachodnie, relacji z ZSRR jako priorytetowych oraz obawy, iż krytyka działań M. Gorbaczowa - w opinii Zachodu prowadzacego korzystna dla tego bloku polityke, mogłaby doprowadzić do osłabienia jego pozycji w państwie. Wskazana sytuacja zaczęła się jednak zmieniać ze względu na ujawnienie już pod koniec stycznia 1990 r. prawdy o tragicznych wydarzeniach, przekazanej nastepnie przez media, światowej opinii publicznej. W ostatecznym bilansie rola Zachodu $w$ tej kwestii byta neutralna.

Ze względu na ograniczenia objętościowe artykułu i kwestie merytoryczne, zastosowany został ogranicznik czasowy - rozpatrywany jest okres od 19 stycznia $1990 \mathrm{r}$. do momentu upowszechnienia pierwszych informacji ukazujących prawdę o „Czarnym Styczniu” i zmiany stanowiska odnośnie powyższych zdarzeń przez najważniejsze państwa Zachodu. Wynika to $z$ faktu, iż wskazany okres jest kluczowy dla badania i zrozumienia tytułowej problematyki. W następnych latach, aż do dnia dzisiejszego obserwowana jest kontynuacja zaistniałej wówczas tendencji. Podjęte badania (ogranicznik terytorialny) ograniczają się do terytorium ZSRR, a zwłaszcza będącej jego częścią Azerbejdżańskiej Socjalistycznej Republiki Radzieckiej oraz najistotniejszych państw Zachodu. Wskazane podmioty są najważniejsze dla badanej problematyki gdyż przesądzają o jej charakterze. Zastosowanie ogranicznika przedmiotowego wynika z faktu, iż badana jest głównie opinia mediów i polityków najistotniejszych państw zachodnich. Poza kwestiami objętościowymi, takie podejście uwarunkowane jest tym, iż to te kwestie są najistotniejsze biorąc pod uwagę decyzje polityczne wskazanych podmiotów (państw).

\section{Interwencja wojsk radzieckich w Baku 19/20 stycznia 1990 r.}

$\mathrm{Na}$ wstępie należy odnieść się do samych wydarzeń znanych jako „Czarny Styczeń”. Prawdziwą przyczyną zbrodniczych działań armii radzieckiej była chęć zdławienia działalności opozycyjnego Ludowego Frontu Azerbejdżanu, oraz nastrojów narodowościowych panujących wśród Azerbejdżan mających na względzie obronę integralności terytorialnej Azerbejdżańskiej $S_{R R}{ }^{206}$. Spowodowane one były w dużej mierze wcześniejszymi wydarzeniami. 20 lutego 1988 r. władze Górskiego Karabachu będącego częścią Azerbejdżańskiej SRR złożyły wniosek o przyłączenie do Armeńskiej SRR. 1 grudnia 1989 r. Rada Najwyższa wskazanej republiki ogłosiła włączenie powyższego regionu w jej skład. Na przełomie listopada i grudnia 1988 r. uzbrojone grupy mieszkańców (Ormian) Armeńskiej Socjalistycznej Republiki Radzieckiej, przy wsparciu Partii Komunistycznej Armenii i władz republikańskich wypędziły ok. 200000 Azerbejdżan, zamieszkujących wskazaną republikę. W trakcie tego procederu zginęło 216 osób w tym 57 kobiet, 5 niemowląt i 18 dzieci $^{207}$. Pozostawiając cały dobytek, tłumy uchodźców trafiły w większości do Baku. Oburzenie Azerbejdżan wywołały zarówno same wydarzenia jak i całkowity brak

\footnotetext{
206 А. Джамиль оглу Гулиев, Черный январь: мы должны знать всю правду, [w:] Версии.сот, zа: http://versii.com/news/374710/ (10.03.2020).

${ }^{207}$ S. Kolarz, Status prawny Górskiego Karabachu - porównanie ze statusem prawnym Kosowa [w:] „Folia Iuridica Universitatis Wratislaviensis", 2016, vol. 5 (1), s. 122.
} 
reakcji władz centralnych $Z_{S R R}{ }^{208}$. Pozostawienie przez Kreml obywateli Związku Radzieckiego (Azerbejdżan) bez obrony przed wskazanymi praktykami spowodowało zerwanie identyfikacji większości mieszkańców Azerbejdżańskiej Socjalistycznej Republiki Radzieckiej ze Związkiem Radzieckim, który przestawał być postrzegany jako własne państwo.

Interwencję wojsk radzieckich poprzedziło przybycie do Baku 19 stycznia $1990 \mathrm{r}$. Dmitrija Jazowa Ministra Obrony ZSRR oraz Wadima Bakatina Ministra Spraw Wewnętrznych ZSRR, którzy mieli na miejscu kierować działaniami sił radzieckich. W tym samym czasie działalność rozpoczęły jednostki specnazu, co miało miejsce jeszcze przed wprowadzeniem stanu wyjątkowego, który miał obowiązywać od północy 20 stycznia 1990 r. ${ }^{209}$ Od samego początku władze radzieckie równolegle $\mathrm{z}$ interwencją prowadziły działania mające na celu niedopuszczenie do ujawnienia prawdy o „Czarnym Styczniu”. Z tego względu 19 stycznia 1990 r. grupy szturmowe „Wympieł” i „Alfa” wysadziły w powietrze bloki energetyczne telewizji azerbejdżańskiej. Zaaranżowane przez władze, chuligańskie zachowania mające miejsce tuż przed działaniami wojsk radzieckich jak rabunki, podpalenia samochodów itd. posłużyły natomiast, jako oficjalny powód prośby władz lokalnych do władz centralnych, o interwencję zbrojną. Około północy rozpoczęły się działania 26 tysięcy żołnierzy ${ }^{210}$. Do Baku wjechały czołgi, a od morza nastąpił desant floty kaspijskiej ${ }^{211}$. Wojsko wyposażone było w niedozwoloną przez umowy międzynarodowe amunicję, o zmienionym środku ciężkości, co zwiększa śmiertelność wśród postrzelonych osób. Do działań użyte zostały także śmigłowce wojskowe. Celem byli całkowicie zaskoczeni cywile - mieszkańcy Baku. Żołnierze strzelali bez ostrzeżenia do przypadkowych osób - przechodniów, ludzi chcących przeparkować samochód czy zaniepokojonych hałasem, obserwujących z okien wydarzenia. Niektórzy zginęli pod gąsienicami czołgów ${ }^{212}$. M.in. kilku naukowców jadących samochodem na Uniwersytet poniosło śmierć, gdy został on zmiażdżony przez pojazd pancerny. O bezwzględności i innych intencjach działań wojska niż deklarowane zaprowadzenie porządku w mieście, rzekomo opanowanym przez grupy wandali i chuliganów, świadczy też odcięcie prądu w szpitalach, co w dużej mierze utrudniło, a czasami uniemożliwiło pomoc rannym. Zwolniony został także personel pogotowia. Obserwowano przypadki wandalizmu i kradzieży interweniujących żołnierzy. W celu ukrycia popełnionych zbrodni wiele ciał zostało spalonych. Stąd oprócz ofiar i rannych odnotowano

\footnotetext{
208 P.A. Goble, Black January in Baku - the time and place the Soviet Union died, za: http://euromaidanpress.com/2019/01/22/black-january-in-baku-the-time-and-place-the-soviet-union-died/ (14.03.2020).

${ }^{209}$ Istotną kwestią jest też fakt, iż informacja o wprowadzeniu stanu wyjątkowego została podana do publicznej wiadomości dopiero o godz. 5:30, 20 styczna $1990 \mathrm{r}$.

${ }^{210}$ Duża część interweniujących żołnierzy była pochodzenia ormiańskiego, co było celowym działaniem władz centralnych, mającym na celu zwiększenie brutalności interwencji.

${ }^{211}$ P. Kwiatkiewicz: Przemiany polityczne w Azerbejdżanie. Od republiki radzieckiej do współczesnego państwa. Toruń: Wydawnictwo Adam Marszałek, 2013, s. 169-171.

212 А. Джамиль оглу Гулиев, Черный январь:, op. cit.
} 
też wiele osób zaginionych ${ }^{213}$. Łącznie zabitych zostało co najmniej 133 osoby, 611 zostało rannych $^{214}$, a 400 uznano za zaginione ${ }^{215}$.

\section{Pierwsze reakcje Zachodu na wydarzenia „Czarnego Stycznia”}

Przechodząc do szczegółowej analizy reakcji Zachodu na wskazane wyżej wydarzenia należy stwierdzić, iż dominowało stwierdzenie, że jest to wewnętrzna sprawa Związku Radzieckiego, jak powiedział m.in. włoski Minister Spraw Zagranicznych D. Michelsa. Chociaż, już takie podejście budzi niezrozumienie i pytanie o troskę państw zachodnich o prawa człowieka, to trzeba wskazać, że rządy najważniejszych członków bloku zachodniego nie poprzestały na takim stwierdzeniu. Amerykański Prezydent George Bush zaznaczył, że Gorbaczow wykonał "niezwykłą pracę" w radzeniu sobie z sytuacją w Azerbejdżanie, starając się w ten sposób usprawiedliwić represyjną działalność Kremla. M. Tatuiler Rzeczniczka Departamentu Stanu USA, wypowiadając się w imieniu tego państwa stwierdziła, że działania podjęte przez władze ZSRR miały na celu utrzymanie pokoju między dwoma wojującymi stronami. $\mathrm{W}$ podobnym tonie wyrażała się przedstawicielka innego ważnego państwa świata zachodniego - Premier Wielkiej Brytanii Margaret Thatcher stwierdziła, przemawiając w Izbie Gmin, iż „,ma wielką sympatię” do M. Gorbaczowa, ponieważ „stara się uchronić naród przed rozpadem" 216 . Jak więc widać przywódcy najważniejszych państw zachodnich nie tylko, nie krytykowali ZSRR za działania przeciwko Azerbejdżanom, ale nawet pochwalali je. W podobnym tonie utrzymane były informacje w prasie zachodniej. Na łamach „Sandy Express" można było przeczytać, iż: "Szczerze mówiąc, Gorbaczow nie miał innego wyjścia, jak wysłać żołnierzy". The New York Times, w numerze, który ukazał się w dniu tragedii napisał „sytuacja w Azerbejdżanie stała się tak niebezpieczna, w opinii ogółu badanych osób, że Gorbaczow nie miał innego wyjścia, jak tylko nakazać wprowadzenie oddziałów do tego obszaru", a 22 stycznia, pisze: "... thumienie przez wojsko powstania etnicznego w tej republice cieszy się szerokim, jeśli nie entuzjastycznym wsparciem w kraju”. Korespondent BBC, M. Saxsmith donosi: "My w Wielkiej Brytanii, z naszym gorzkim doświadczeniem konfliktu w Irlandii Północnej, mamy wszelkie powody, by sympatyzować z przywódcą radzieckim, przed którym stoi nierozwiązywalne zadanie zachowania pokoju między dwoma wojującymi narodami za pomocą trzeciej siły, której oba nie uznają za swoją własną". „Sandy Express" pisze w artykule redakcyjnym: "Szczerze mówiąc, Gorbaczow nie miał innego wyboru, jak wysłać żołnierzy." 217 Jak więc widać wskazane na wstępie stwierdzenie, iż zarówno rządy jak i media głównych państw zachodu wspierały styczniową interwencję $\mathrm{M}$. Gorbaczowa w Azerbejdżańskiej SRR, w której zginęło sto kilkadziesiąt osób - cywili, głównie mieszkańców Baku, a kilkaset zostało rannych nie jest bezpodstawne.

\footnotetext{
${ }^{213}$ Ibidem.

${ }^{214}$ Н. Мусави, "Танки давили и обстреливали все подряд". Очевидиы и участники событий 1990 года в Баку вспоминают "черныцй январь", za: https:/www.currenttime.tv/a/azerbaizan-baku-blackjanuary/30381785.html (17.03.2020).

215 А. Худиев, Кровавый «Черный январь», za: http://ozan.ru/krovavyj-chernyj-yanvar/ (17.03.2020).

216 Черный январь и мир. Общество, za: http://www.kaspiy.az/news.php?id=96536 (20.03.2020).

${ }^{217}$ Ibidem.
} 
Przechodząc do wyjaśnienia przyczyn tego niezrozumiałego zjawiska, należy wskazać, iż tragiczne wydarzenia, o których mówimy miały miejsce w Azerbejdżańskiej Socjalistycznej Republice Radzieckiej, która była częścią Związku Radzieckiego, czyli państwa niewahającego się użyć wszelkich środków do osiągnięcia własnych celów. Gorbaczow, stosując starą szkołę radziecką, dążył do tego, aby dokonana z premedytacją zbrodnia, jakiej dopuścił się na narodzie azerbejdżańskim, protestującym przeciwko nierównemu traktowaniu w stosunku do Ormian i akceptowaniu przez władze ZSRR aktów przemocy wobec poszczególnych osób oraz Azerbejdżańskiej SRR, której część Armeńska SSR chciała przyłączyć do swojego terytorium, nie wyszła na jaw. Ofiary starał się natomiast przedstawić jako winnych. Zadanie to ułatwiał fakt, iż ZSRR, jako państwo totalitarne i tak sprawowało ścisłą kontrolę nad tym, co pojawiało się w opinii publicznej. Przygotowując się jednak do tego, co stało się 19 i 20 stycznia 1990 r. już od 4 stycznia 1990 r. obcokrajowcy nie mogli wjeżdżać do Baku, co oznacza, że zachodni reporterzy nie mogli donieść o kolejnym łańcuchu niepokojów i represji. Pozostała jeszcze kwestia radia i telewizji. 19 stycznia wybuch zniszczył centrum nadawcze ${ }^{218}$ - wielu ekspertów, m.in. z Human Rights Watch wskazuje, że były to działania władz centralnych ZSRR. W wyniku eksplozji na terenie Azerbejdżańskiej SRR nie było radia ani telewizji. Dzięki wskazanym działaniom, władze ZSRR uzyskały monopol na informację o zdarzeniach w tej republice. Jeszcze przed masakrą ludności cywilnej, władze Związku Radzieckiego podawały społeczności zachodniej, nieprawdziwe informacje, o ciągłym prześladowaniu Ormian przez Azerbejdżan, choć w rzeczywistości było odwrotnie. W ten sposób M. Gorbaczow przygotowywał warstwę propagandową swoich działań, co miało doprowadzić do pozyskania wsparcia dla nich, zachodnich rządów i mediów, a przez to i tamtejszych społeczeństw. Miały być postrzegane, jako mające na celu stabilizację otwartego konfliktu Azerbejdżańskiej SRR z Armeńską SRR wywołanego przez pierwsze ze wskazanych państw. W efekcie wspomnianych przygotowań Związek Radziecki miał odnieść podwójny sukces - zdławić ruchy społeczne, akcentujące narodową tożsamość i interes Azerbejdżan, a za swoje zbrodnicze działanie zyskać uznanie i pochwałę Zachodu. Analizując przytoczone powyżej reakcje najważniejszych państw zachodnich oraz mediów, należy stwierdzić, że drugi ze wskazanych celów, przynajmniej w okresie, zaraz po 20 stycznia 1990 r., udało się osiągnąć. Wydaje się jednak, że aby uzyskać powyższy efekt, oprócz przytoczonych działań konieczne było jeszcze oddziaływanie innych czynników. Opisana reakcja Zachodu, przyjmującego radziecką narrację, była możliwa dzięki postrzeganiu przez najważniejsze państwa tego bloku, relacji ze ZSRR, jako priorytetowej, a polityki M. Gorbaczowa, jako korzystnej dla Zachodu, co obligowało do wspierania tej postaci na arenie międzynarodowej, aby wzmocnić jego pozycję w państwie. Stwierdzenia takie popiera chociażby informacja zamieszczona w "Washington Post" z 21 stycznia, która głosi, iż: „Ponieważ konflikty etniczne i secesjonistyczne burzą Związek Sowiecki, urzędnicy amerykańscy zostali zmuszeni do uznania, że Stany Zjednoczone powinny działać na rzecz przetrwaniu prezydenta Michaiła Gorbaczowa"219. Gdy mamy już pełną informację o tamtejszych realiach - postrzeganiu M. Gorbaczowa przez Zachód i jedynym źródle informacji o wydarzeniach w Azerbejdżańskiej SRR pochodzącym od władz ZSRR, reakcja

\footnotetext{
${ }^{218}$ P. Kwiatkiewicz: Przemiany polityczne... op.cit., s. 169-171.

219 Черный январь..., ор. cit.
} 
Zachodu staje się bardziej zrozumiała, co nie znaczy, że akceptowalna. Z jednej strony państwa zachodnie były przekonywane przez ZSRR, że Azerbejdżanie są agresywni wobec Ormian, więc władze Związku Radzieckiego działają z pobudek humanitarnych, w obronie słabszych. Z drugiej zaś taki przekaz był pożądany przez państwa zachodnie, gdyż usprawiedliwiał poparcie działań M. Gorbaczowa, co dla zachodu było w tamtym okresie priorytetem.

\section{Przelamanie blokady informacyjnej - zmiana opinii Zachodu o wydarzeniach w Baku z 19/20 stycznia 1990 r.}

Mimo działań władz radzieckich nie udało się całkowicie odciąć społeczności międzynarodowej od prawdziwych informacji na temat tego, co określane jest dzisiaj jako „Czarny Styczeń”. Wskazaną blokadę przełamała gazeta „Seher”. Przedstawiła ona, co naprawdę stało się 19 i 20 stycznia 1990 r. 25 stycznia 1990 r. ukazał się pierwszy nr poświęcony wydarzeniom „Czarnego Stycznia”. Opublikowany został obszerny materiał (11 stron) zawierający reportaż i zdjęcia. Aby gazeta mogła zostać wydana i rozpowszechniona, na końcu części dotyczącej tragicznych wydarzeń zamieszczona została adnotacja „Zamówienie nr 1" centralnych władz radzieckich ogłaszające stan wyjątkowy. Bezprecedensowy był nakład gazety - $2 \mathrm{mln}$. egzemplarzy przy ówczesnej populacji Azerbejdżańskiej SRR wynoszącej blisko $8 \mathrm{mln}$. Taki wynik nie został powtórzony do dzisiaj przez żadną gazetę. Aby zwiększyć zasięg oddziaływania cały nakład został rozwieziony do różnych regionów republiki i rozdany za darmo. Część osób wklejało gazetę w okna, aby jeszcze więcej czytelników mogło się z nią zapoznać. Odnotowane zostały incydenty, podczas których żołnierze radzieccy strzelali do takich okien po tym jak zgromadzeni przed nimi mieszkańcy, nie chcieli się rozejść. 3 lutego 1990 r. na łamach „Seher” ukazała się pełna lista ofiar - imiona i nazwiska. Aby oszukać cenzurę została opublikowana, jako spis kandydatów do nadchodzących wyborów ${ }^{220}$.

Wszystko to było możliwe dzięki redaktorowi powyższej gazety Mazahir Suleymanzade, który oszukując cenzurę ujawnił prawdziwe oblicze „Czarnego Stycznia”. Gazeta stała się wkrótce głównym źródłem informacji dla BBC i $\mathrm{CNN}^{221}$.

Druga luka w blokadzie informacyjnej powstała w wyniku działań, paryskiego fotoreportera pochodzenia azerbejdżańskiego, Rezy Deghati. Z cząstkowych relacji w serwisach informacyjnych wynikało, iż sytuacja w Azerbejdżańskiej Socjalistycznej Republice Radzieckiej bardzo się komplikuje. Aby to potwierdzić skontaktował się $\mathrm{z}$ przyjaciółmi - Ahmedem Sale, tureckim operatorem pracującym w ZSRR dla francuskiej firmy telewizyjnej oraz wybitnym pisarzem Rustamem Ibrahimbeyov. Do Moskwy przyleciał wraz z dwoma znajomymi 21 stycznia 1990 r. Na miejscu byli też dziennikarze z CNN, ABC, CBS, NBC, Reuters i AP. Posiadali jedynie informacje o demonstracjach i wkroczeniu wojsk radzieckich do Baku. Władze ZSRR nie chcąc, aby prawda o wydarzeniach z 19/20 stycznia 1990 r. została ujawniona, a z drugiej strony, żeby uniknąć oskarżenia o jej ukrywanie

\footnotetext{
${ }^{220}$ Tom Marsden, Breaking the Silence How Seher newspaper broke the information blockade to report on Black January, za: http://www.visions.az/en/news/763/ed785d31/ (19.03.2020).

${ }^{221}$ Ibidem.
} 
zastosowały wobec dziennikarzy swego rodzaju fortel. Zakomunikowały, iż w związku z faktem, że w Związku Radzieckim panuje zasada transparentności w kwestii wydarzeń w państwie, nie tylko zgadzają się na wizytę przedstawicieli światowych mediów w stolicy Azerbejdżańskiej SRR, ale dla ułatwienia zorganizują samolot dla wszystkich reporterów. Nikt poza Rezą Deghati nie domyślał się podstępu. Jak się później okazało samolot nie doleciał do Baku - pilot, nad Kaukazem oznajmił, iż zostało ono zamknięte i lądowanie odbyło się w najbliższym możliwym miejscu, czyli „,przez przypadek” w stolicy Armeńskiej SRR, gdzie na reporterów czekali już zorganizowani przez radziecką prasę Ormianie, którzy przedstawili swoją wersję, w której Azerbejdżanie opisywani byli w bardzo negatywnym świetle. Dzięki temu ZSRR nie tylko nie ujawniła prawdy o „Czarnym Styczniu”, ale wręcz narzuciła własną narrację, unikając przy tym oskarżeń o utrudnianie pracy zagranicznym mediom. Dlatego tak ważna była misja R. Deghati i pozostałych dwóch osób, z którymi przyleciał z Paryża. Znając sposób działania władz na Kremlu, jako jedyni nie zdecydowali się na wskazaną propozycję. Postanowili dotrzeć do Baku lokalnymi pociągami, co zajęło im ok. 48 godz. Taki sposób dawał jednak największe szanse na dotarcie do celu (mniej kontroli niż w pociągach ekspresowych). Na miejscu byli 24 stycznia 1990 r. - udając miejscowych. Mieszkali u zorganizowanych wcześniej rodzin. Kilka niedużych kamer i aparatów zostało przeniesionych z pociągu przez podstawione osoby - aby nie zdradziły celu ich podróży w przypadku kontroli. Fotoreporterowi udało się zrobić wiele poruszających zdjęć $-\mathrm{m}$.in. ze szpitali, kostnicy, czołgów na ulicach oraz wielkiego zgromadzenia na Shahidlar Hiyabani (Cmentarz Męczenników - ofiar wydarzeń Czarnego Stycznia). Po powrocie do Paryża jeszcze tego samego dnia o 20:00 wyemitowany został w telewizji materiał zmontowany z nagrań z Baku. Było to pierwsze źródło, obok wskazanego wcześniej, prawdziwych informacji o wydarzeniach w stolicy Azerbejdżańskiej SRR z 19/20 stycznia 1990 r. Zdjęcia zostały przekazane agencji mogącej przekazać je ok. 2000 czasopism i gazet na całym świecie. W efekcie informacje o zbrodniach ZSRR popełnionych na cywilnych mieszkańcach Baku zostały rozpowszechnione na całym świecie. Ponad 18 kanałów telewizyjnych i dziesiątki stacji radiowych zaprosiły uczestników ryzykownej misji do swoich programów $^{222}$.

Dzięki takim działaniom jak redaktora Mazahira Suleymanzade i fotoreportera Rezy Deghati prawda o „Czarnym Styczniu” zaczęła stopniowo dochodzić do zachodnich mediów, a za ich pośrednictwem do tamtejszych społeczeństw co było jednym z głównych czynników wpływających na zmianę opinii mieszkańców i rządów państw tej części świata o wydarzeniach mających miejsce w Baku 19/20 stycznia 1990 r.

\section{Zakończenie}

Przytoczone fakty potwierdzają stwierdzenie zawarte w hipotezie, przedstawionej na wstępie, iż: reakcja państw i mediów zachodnich, $w$ dużej mierze wspierających działania ZSRR na terytorium Azerbejdżańskiej SRR była głównie wynikiem wcześniejszych działań Zwiazku Radzieckiego - blokady informacyjnej, zastosowanej na dtugo przed wydarzeniami

\footnotetext{
${ }^{222}$ R. Deghati, B. Blair, Black January: Baku (1990) Behind the Scenes - A Photojournalist's Perspective [w:]

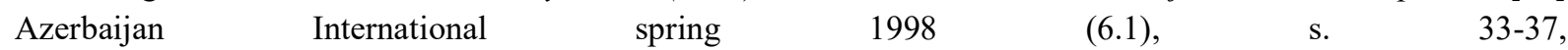
https://azer.com/aiweb/categories/magazine/61_folder/61_articles/61_blackjanuary.html (21.04.2020).
} 
zwanymi Czarnym Styczniem $i$ propagandy ZSRR ukazujacej nieprawdziwy obraz Azerbejdżan, jako strony inicjujacej konflikt z Armeńska SRR i stosujacej przemoc wobec Ormian. Powściagliwość, a nawet aprobata wyrażona przez duża część państw Zachodu, wobec krwawej interwencji wojsk radzieckich $w$ Azerbejdżańskiej SRR nie byłaby jednak faktem, gdyby nie postrzeganie przez państwa zachodnie, relacji z ZSRR jako priorytetowych oraz obawy, iż krytyka działań M. Gorbaczowa - w opinii Zachodu prowadzacego korzystna dla tego bloku polityke, mogłaby doprowadzić do osłabienia jego pozycji w państwie. Wskazana sytuacja zaczęła się jednak zmieniać ze względu na ujawnienie już pod koniec stycznia 1990 r. prawdy o tragicznych wydarzeniach, przekazanej nastepnie przez media, światowej opinii publicznej. W ostatecznym bilansie rola Zachodu $w$ tej kwestii była neutralna.

Podsumowując należy stwierdzić, iż jeden $\mathrm{z}$ celów interwencji radzieckiej zniszczenie świadomości narodowej Azerbejdżan i ich dążenia do obrony swoich racji, nie został osiągnięty - można powiedzieć, że skutki były odwrotne, od zaplanowanych Azerbejdżanie podjęli decyzję o konieczności opuszczenia ZSRR. Drugi z celów, przekonanie Zachodu o tym, że za napięcie w relacjach z Ormianami winę ponoszą Azerbejdżanie, został na krótko zrealizowany. Sukces ten wynikał jednak w dużej mierze $\mathrm{z}$ tego, że Zachód nie chciał krytykować M. Gorbaczowa, uważając że jego polityka jest korzystna dla Zachodu. Jednak po rozpadzie ZSRR, gdy wskazany powód już nie był aktualny, a prawdziwych informacji na temat „Czarnego Stycznia” było coraz więcej, opinia Zachodu zaczęła stopniowo zmieniać się na korzyść Azerbejdżanu. Można więc powiedzieć, że w ostatecznym rozrachunku, działania władz centralnych ZSRR z 19 i 20 stycznia, zarówno w sferze taktycznej - złamanie ducha narodowego Azerbejdżan jak i informacyjnej - narzucenie narracji o wskazanych wydarzeniach stawiającej w negatywnym świetle mieszkańców Baku i usprawiedliwiającej działania radzieckie, dodatkowo przedstawione w zdeformowanym na korzyść Kremla kształcie, poniosły całkowitą klęskę.

\section{Streszczenie:}

Artykuł dotyczy reakcji świata zachodniego na interwencję wojsk radzieckich w Baku w dniach 19/20 stycznia 1990 r., która przeszła do historii jako „Czarny Styczeń”. Autor próbuje odpowiedzieć na pytanie, dlaczego opinia zachodnich mediów i rządów była nieprzychylna mieszkańcom Azerbejdżańskiej Socjalistycznej Republiki Radzieckiej, pomimo faktu, iż to Azerbejdżanie byli ofiarami a władze centralne ZSRR i wojsko sprawcami oraz co spowodowało zmianę w tym względzie w późniejszym okresie. Tekst składa się z trzech części. W pierwszej w skrótowy sposób przedstawione zostały wydarzenia dotyczące działań Kremla i armii radzieckiej w ASRR w dniach 19/20 stycznia 1990 r. Kolejna poświęcona jest pierwszym reakcjom świata zachodniego na wskazane wydarzenia. W trzeciej Autor koncentruje się na dalszej perspektywie, związanej ze zmianą postrzegania przez Zachód, interwencji władz centralnych ZSRR w Baku na początku 1990 r. Takie ujęcie badanej problematyki pozwoliło odpowiedzieć na wskazane wyżej pytanie i zweryfikowanie związaną z nim hipotezy badawczej. 


\section{Słowa kluczowe:}

Azerbejdżańska Socjalistyczna Republika Radziecka, Związek Radziecki, Baku, „Czarny Styczeń", opinia świata zachodniego, blokada informacyjna

\section{Key words:}

Azerbaijani Soviet Socialist Republic, Soviet Union, Baku, "Black January", Western world opinion, information blockade

\section{Bibliografia:}

1. Ариф Джамиль оглу Гулиев, Черный январь: мы должны знать всю правду, [w:] Версии.com, za: http://versii.com/news/374710/ (10.03.2020).

2. Азер Худиев, Кровавый «Черный январь», za: http://ozan.ru/krovavyj-chernyjyanvar/ Черный январь $и$ мир. Общество, zа: http://www.kaspiy.az/news.php?id=96536

3. Черный январь и мир. Общество, za: http://www.kaspiy.az/news.php?id=96536

4. Н. Мусави, "Танки давили и обстреливали все подряд". Очевидиы и участники событий 1990 года в Баку вспоминают "черный январь", ва: https://www.currenttime.tv/a/azerbaizan-baku-black-january/30381785.html

5. P.A. Goble, Black January in Baku - the time and place the Soviet Union died, za: http://euromaidanpress.com/2019/01/22/black-january-in-baku-the-time-and-placethe-soviet-union-died/ (14.03.2020).

6. P. Kwiatkiewicz: Przemiany polityczne w Azerbejdżanie. Od republiki radzieckiej do współczesnego państwa. Toruń: Wydawnictwo Adam Marszałek, 2013, s. 169-171.

7. R. Deghati, B. Blair, Black January: Baku (1990) Behind the Scenes - A Photojournalist's Perspective [w:] Azerbaijan International spring 1998 (6.1) , s. 3337,https://azer.com/aiweb/categories/magazine/61_folder/61_articles/61_blackjanuary. html

8. S. Kolarz, Status prawny Górskiego Karabachu - porównanie ze statusem prawnym Kosowa [w:] „Folia Iuridica Universitatis Wratislaviensis”, 2016, vol. 5 (1), s. 122.

9. T. Marsden, Breaking the Silence How Seher newspaper broke the information blockade to report on Black January, za: http://www.visions.az/en/news/763/ed785d31/ 